\title{
Elongation of Saccharide Chain by Polymer-supported Glycosylation
}

\author{
ポリマー担持グリコシル化による糖鎖伸長
}

\author{
Danishefsky, S. J., McClure, K. F., Randolph, J. T., and Ruggeri, R. B. (1993) Science 260, 1307-1309
}

Key Words: oligosaccharide, polymer-supported glycosylation, solid-phase glycosylation

Primary structures of nucleic acids and proteins are all arranged only by the genetic code. On the other hand, in vivo, saccharide chains are synthesized by the regioselective actions of many kinds of enzymes such as glycosidases and glycosyl transferases at a specific time. Chemical synthesis of saccharide chain is more complicated because carbohydrates are multi-functional. Enzymatic glycosylation can be achieved on a particular hydroxyl group by the unique structure of the enzyme, whereas in chemical glycosylation, it is necessary to protect the hydroxyl groups which do not participate in the glycosylation reaction. Moreover, it is quite difficult to control the stereospecificity ( $\alpha$ or $\beta$ ) in the chemical synthesis of oligosaccharides.

Therefore, while DNA synthesizer and peptide synthesizer are on the market, no oligosaccharide synthesizer has been developed yet. However, solid-phase synthesis of oligosaccharide as an initial step towards the development of an oligosaccharide synthesizer was recently reported in Science. The polymer-support of the oligosaccharide allows even excessive of reagents which can be easily removed by rinsing.

The authors investigated the polymer-supported glycosylation, paying attention to the following points; i) ease of polymer support of starting material, ii) easy handling of protective groups, iii) high stereospecificity of glycosylation, iv) easy isolation of the obtained oligosaccharide (detachment from the polymer), v) no deletions in the synthesized oligosaccharide.

There are two ways to attach the saccharide chain to the polymer support. One is the attachment with the glycosyl bond at the reducing end, and the other one is the attachment with the ether bond at the non-reducing end. The authors selected the latter process in which polymer-supported saccharide would act as a glycosyl donor in each glycosylation reaction. At the initial stage, the glycal derivative protected by cyclic carbonate at C-3 and C-4 is attached to the styrene copolymer with a silyl ether bond. After the oxidation of the double bond to the epoxide ring (1,2-anhydrosugar derivative), the polymer-supported 1,2-anhydrosugar derivative is reacted with another glycal derivative having a free hydroxyl group at the specific position at which the glycosidic linkage will be formed. Elongation of the saccharide chain is achieved by repeating the reaction process described above. The synthesized oligosaccharide
核酸やタンパク質におけるヌクレオチドやアミノ酸の一次 配列が遺伝情報によって決定論的に定まっているのに対して、 糖鎖部分は幾種類もの酵素(加水分解酵素と転移酵素)が特定の 時期に特定の場所で働くことの繰り返しによって生合成され る。糖分子は多官能であるため、糖鎖の化学合成はさらに複雑 である。なぜなら、生体反応では、酵素の特殊な構造を利用し て、特定の水酸基のみを反応させることが可能であるが、化学 反応においては、反応しない水酸基を適当な保護基でブロック する必要があるからである。さらに、オリゴ糖鎖の合成におい ては、アノマー炭素の立体配置 $(\alpha$ または $\beta$ )の制御も非常に困 難である。

したがって、核酸やポリペプチドの自動合成装置が市販さ れているのに対して、糖鎖の自動合成装置は開発されていない のである。しかしながら、糖鎖自動合成装置開発の第一歩とも 言える固相オリゴ糖合成反応が最近開発され、Scienceに報告さ れた。核酸やポリペプチドの合成装置がそうであるように、生 成物を固相に固定することにより、系中に存在する大過剩の試 薬と容易に分離することができる。

この文献の著者らは、次の5つの項目に注目して研究を 行った。即ち、i)出発物質が簡単にポリマーと結合すること、ii) 保護基の取り扱いが容易であること、iii)グリコシル化の立体選 択性が高いこと、iv)生成オリゴ糖の単離(ポリマーからの分離) の容易さ、v)オリゴ糖鎖に欠落がないこと。

糖鎖をポリマーに結合する方法としては、還元末端で結合 する方法と非還元末端で結合する方法が考えられるが、著者ら は後者を選び、各グリコシル化反応においては、ポリマーに結 合した糖がグリコシルドナーとなるように設計した。まず、3、 4位を保護したグリカール化合物の6位をスチレンコポリマーと シリルエーテル結合で結合させる。二重結合を酸化してエポキ シ化合物(1,2-無水糖誘導体)とした後、特定位置(グリコシド結 合が形成される位置)にフリーの水酸基を有する別のグリカール と反応させ糖鎖を伸長させるのである。この反応の繰り返しに より糖鎖伸長を行い、最後に、フッ素アニオンを用いてポリス 
is finally detached from the styrene copolymer by the use of fluoride ion.

It is noteworthy that, in the proposed process, the precursor of the glycosyl donor for the next glycosylation reaction (glycal) is already introduced into the glycosyl acceptor reagent, and the precursor is changed to the glycosyl donor (epoxide) after the first glycosylation. In this manner the stepwise elongation of the polymer-supported oligosaccharide chain can be carried out. Moreover, the excellent points of this method are high quantity and stereospecificity of epoxidation and the perfect inversion of the anomeric center during the glycosylation reaction.

However, there are a few disadvantages to this method. For example, as described by the authors, it is necessary to purify the obtained oligosaccharide because of the deletion in the the saccharide chain caused by the hydrolysis of epoxide ring during rinsing. This phenomenon becomes more serious for a longer oligosaccharide chain. Furthermore, $(1 \rightarrow 2)$-linked glycoside cannot be synthesized by this method, and this method has to be improved in order to synthesize a branched polysaccharide. However, even if the completion of the oligosaccharide synthesizer does pose some problems, it should be highly appreciated that the authors took the initial step towards the oligosaccharide synthesizer.

In the XVth Japanese Carbohydrate Symposium (July 1993, Sendai), Dr. S. Hanessian reported on a solid-phase glycosylation in his invited lecture, and further development in this field is expected.

\section{Reported by Hatanaka, $K$.}

Department of Biomolecular Engineering

Tokyo Institute of Technology

Midori-ku, Yokohama 227, Japan
チレンから切り離すのである。

この反応の注目すべき点は、グリコシル化反応のアクセプ ター化合物に次のグリコシル化反応のドナー前駆体(グリカー ル)を導入し、カップリング反応後に活性化(エポキシ化)してグ リコシルドナーとする点にある。このようにして、ポリスチレ ン上に担持された糖残基を一つずつ増やしていく段階的な糖鎖 伸長が可能となった。さらに、エポキシ化の反応が定量的かつ 立体選択的に進行し、エポキシ環の開裂がアノマー中心におけ る立体配置の反転を伴う $\mathrm{S}_{\mathrm{N}}$ 機構により進行することが、この方 法の優れている点である。

しかしながら、この方法にも欠点はいくつかある。例え ば、著者らが指摘しているように、カップリング反応後に反応 溶液をリンスする際に1,2-無水糖のエポキシ環が加水分解し、 糖鎖伸長が止まってしまうため、生成物であるオリゴ糖鎖の精 製が必要となってくることである。このことは、オリゴ糖鎖の 長さが長くなるほど重要な問題となってくる。また、この方法 では(1 $\rightarrow 2)$-結合の糖鎖は合成できない。さらに、糖鎖の特徴で ある分岐という観点からも改良が必要であろう。糖鎖の自動合 成装置を完成させるために改良すべき問題点はいくつかある が、固相グリコシル化という第一歩を踏み出したことは大いに 評価される。

1993年7月の糖質シンポジウム(仙台)においてもS Hanessian博士が糖鎖の固相合成に関する講演を行っており、こ の分野がますます発展することが予想される。

東京工業大学·生命理工学部·生体分子工学科

畑中 研一 